\title{
Global Evaluation of the ISBA-TRIP Continental Hydrological System. Part I: Comparison to GRACE Terrestrial Water Storage Estimates and In Situ River Discharges
}

\author{
R. Alkama, B. Decharme, And H. Douville \\ CNRM-GAME, Météo-France, and CNRS, Toulouse, France \\ M. Becker And A. CAZENAVE \\ CNRS/CNES/Université Toulouse 3, LEGOS/GOHS, Toulouse, France \\ J. SHEFFIELD \\ Department of Civil and Environmental Engineering, Princeton University, Princeton, New Jersey \\ A. Voldoire, S. TytecA, And P. Le Moigne \\ CNRM-GAME, Météo-France, and CNRS, Toulouse, France
}

(Manuscript received 1 September 2009, in final form 12 January 2010)

\begin{abstract}
In earth system models, the partitioning of precipitation among the variations of continental water storage, evapotranspiration, and freshwater runoff to the ocean has a major influence on the terrestrial water and energy budgets and thereby on simulated climate on a wide range of scales. The evaluation of continental hydrology is therefore a crucial task that requires offline simulations driven by realistic atmospheric forcing to avoid the systematic biases commonly found in global atmospheric models. Generally, this evaluation is done mainly by comparison with in situ river discharge data, which does not guarantee that the spatiotemporal distribution of water storage and evapotranspiration is correctly simulated. In this context, the Interactions between Soil, Biosphere, and Atmosphere-Total Runoff Integrating Pathways (ISBA-TRIP) continental hydrological system of the Centre National de Recherches Météorologiques is evaluated by using the additional constraint of terrestrial water storage (TWS) variations derived from three independent gravity field retrievals (datasets) from the Gravity Recovery and Climate Experiment (GRACE). On the one hand, the results show that, in general, ISBA-TRIP captures the seasonal and the interannual variability in both TWS and discharges. GRACE provides an additional constraint on the simulated hydrology and consolidates the former evaluation only based on river discharge observations. On the other hand, results indicate that river storage variations represent a significant contribution to GRACE measurements. While this remark highlights the need to improve the TRIP river routing model for a more useful comparison with GRACE [Decharme et al. (Part II of the present study)], it also suggests that low-resolution gravimetry products do not necessarily represent a strong additional constraint for model evaluation, especially in downstream areas of large river basins where long-term discharge data are available.
\end{abstract}

\section{Introduction}

The exchanges of water, energy, and momentum between the land surface, atmosphere, and ocean exert

Corresponding author address: Ramdane Alkama, CNRMGAME, Météo-France, and CNRS, URA 1357, 42 av. Gaspard Coriolis, 31057 Toulouse, France.

E-mail: ramdane.alkama@cnrm.meteo.fr considerable influence on the global climate system simulated by earth system models (ESMs). The continental freshwater reservoirs represent an active component of the climate system (Dirmeyer 2000, 2001; Douville 2003, 2004; Koster et al. 2000, 2002) and are likely to influence the water and energy exchanges at the land surface, the ocean salinity at the mouths of the largest rivers, and climate at least on the regional scale (Gedney et al. 2000; Douville et al. 2000a,b; Molod et al. 2004; Lawrence and 
Slater 2007; Alkama et al. 2008). The simulation of these processes mainly depends on the representation of the continental part of the global hydrological cycle in continental hydrologic systems (CHSs). Today, CHSs are composed of land surface models (LSMs), which provide realistic lower boundary conditions of temperature and moisture in atmospheric general circulation models (AGCMs), and river routing models (RRMs) used to convert the runoff simulated by the LSMs into river discharge to transfer the continental freshwater into the oceans and then to close the global hydrological cycle. The global evaluation of LSM-RRM systems is therefore a crucial task. This is generally done using offline simulations driven by realistic atmospheric fluxes, such as observed precipitation, to avoid the systematic biases commonly found in AGCMs (Douville 1998; Gedney and Cox 2003; Ngo-Duc et al. 2005; Decharme and Douville 2007; Decharme 2007).

In each grid cell, the evolution of the continental hydrological budget, also called the terrestrial water storage change, can be expressed from the hydrological water balance equation as

$$
\frac{d}{d t} \mathrm{TWS}=P-E-R,
$$

where TWS $\left(\mathrm{kg} \mathrm{m}^{-2}\right)$ is terrestrial water storage, $P$ $\left(\mathrm{kg} \mathrm{m}^{-2} \mathrm{~s}^{-1}\right)$ is precipitation, $E\left(\mathrm{~kg} \mathrm{~m}^{-2} \mathrm{~s}^{-1}\right)$ is evapotranspiration, and $R\left(\mathrm{~kg} \mathrm{~m}^{-2} \mathrm{~s}^{-1}\right)$ is total runoff. Until recently, the evaluation of this budget simulated by CHSs was limited by the lack of global observations and essentially made at the basin scale by the comparison of simulated river discharges with in situ streamflow measurements over the largest basins of the world (Douville 1998; Ngo-Duc et al. 2005; Decharme and Douville 2006a, 2007; Decharme 2007), given a direct evaluation of $R$ in Eq. (1). Today, the earth's time-variable gravity field from the Gravity Recovery and Climate Experiment (GRACE; Tapley et al. 2004) mission lunched in 2002 allows direct evaluation of the simulated TWS. As shown in many studies, GRACE data can be used to estimate TWS from basin (Crowley et al. 2006; Seo et al. 2006) to continent scale (Schmidt et al. 2006; Tapley et al. 2004). Other GRACE applications have been used to estimate groundwater storage variations (Rodell et al. 2004; Yeh et al. 2006), ice sheet and glacier mass loss (Velicogna and Wahr 2006a,b; Chen et al. 2006; Ramillien et al. 2006b), and hydrologic fluxes, including evapotranspiration (Rodell et al. 2004; Ramillien et al. 2006a), precipitation minus evapotranspiration (Swenson and Wahr 2006), and river discharge (Syed et al. 2005).

The main goal of this study is to evaluate the Interactions between Soil, Biosphere, and Atmosphere-Total Runoff Integrating Pathways (ISBA-TRIP) CHS used in the earth system model of the Centre National de Recherches Météorologiques (CNRM), the French meteorological research center. This evaluation is made using GRACE data to evaluate the simulated TWS while simulated river discharge is compared to in situ streamflow measurements. Note that, in Decharme et al. (2010, hereafter Part II), the uncertainties in simulated TWS and discharges due to the TRIP river routing model are investigated in more depth. A brief review of ISBATRIP is provided in section 2. The experimental design and the data used for this evaluation are described in section 3. The main results are presented in section 4 and discussed in section 5. Lastly, the main conclusions are provided in section 6 .

\section{The ISBA-TRIP continental hydrological system}

\section{a. $I S B A$}

ISBA is a relatively simple land surface model (LSM) that uses the force-restore method to calculate the time variation of the surface energy and water budgets (Noilhan and Planton 1989), including snowpack evolution based on a simple one-layer scheme (Douville et al. 1995). The soil hydrology is represented by three layers: a thin surface layer $(1 \mathrm{~cm})$ included in the rooting layer and a third layer to distinguish between the rooting depth and the total soil depth (Boone et al. 1999). An exponential profile of the saturated hydraulic conductivity with soil depth is also assumed for the soil column. This type of profile attempts to represent the fact that roots and organic matter favor the development of macropores and enhance water movement near the soil surface, and that soil compaction is an obstacle for vertical water transport in the deep soil (Decharme et al. 2006). The soil water content varies with surface infiltration, soil evaporation, plant transpiration, and deep drainage. The infiltration rate is computed as the difference between the throughfall rate and the surface runoff. The throughfall rate is the sum of rainfall not intercepted by the canopy, dripping from the interception reservoir and snowmelt from the snowpack.

Recently, a comprehensive parameterization of subgrid hydrology has been included in ISBA to account for the heterogeneity of precipitation, topograph, and vegetation within each grid cell. A TOPMODEL hydrological model approach (Beven and Kirkby 1979) has been used to simulate a saturated fraction where precipitation is entirely converted into surface runoff (Decharme et al. 2006). Infiltration is computed via two subgrid exponential distributions of rainfall intensity and soil maximum infiltration capacity. Lastly, a tile approach, in which each grid cell is divided into a series of subgrid 
patches, is used to represent land cover and soil depth heterogeneities. More details can be found in Decharme and Douville (2006a).

\section{b. TRIP}

TRIP was developed at Tokyo University by Oki and Sud (1998). It is a simple RRM used to convert the daily runoff simulated by ISBA into river discharge on a global river channel network here defined at $1^{\circ} \times 1^{\circ}$ resolution. The runoff part of the simulated TWS can be validated using direct comparison between simulated and observed discharge. TRIP is a simple linear model based on a single prognostic equation for the water mass within each grid cell of the hydrologic network. In other words, TRIP only simulates a surface stream reservoir and the streamflow velocity is assumed constant and uniform at $0.5 \mathrm{~m} \cdot \mathrm{s}^{-1}$.

\section{Experiment design and validation datasets}

\section{a. Experiment design}

ISBA was integrated at $1^{\circ}$ resolution with a 20 -min time step for 1983-2006, where the first three years were considered as spinup. Therefore, only 1986-2006 was used in the evaluation period. Every day, the total runoff (surface runoff + deep drainage) simulated by ISBA was fed into TRIP, which was integrated with a 1-h time step. For the comparison with GRACE data, the monthly TWS simulated by ISBA-TRIP was calculated as the sum of total soil moisture $W$, snow water equivalent $W_{s}$, vegetation interception $W_{r}$, and stream water content $S$ :

$$
\mathrm{TWS}=W+W_{s}+W_{r}+S .
$$

The global meteorological forcing was provided by Princeton University (available online at http://hydrology. princeton.edu) on a 3-hourly time step and at $1^{\circ}$ resolution (Sheffield et al. 2006). This dataset is based on the National Centers for Environmental Prediction-National Center for Atmospheric Research (NCEP-NCAR) reanalysis. Sheffield et al. (2006) have performed corrections of the systematic biases in the 6-hourly NCEP-NCAR reanalyses via hybridization with global monthly gridded observations. In addition, the precipitation is disaggregated in both space and time at $1^{\circ}$ resolution via statistical downscaling and at a 3-hourly time step using information from the 3-hourly Tropical Rainfall Measuring Mission (TRMM) dataset. More detail on this forcing product can be found in Sheffield et al. (2006). Note that, in this study, the atmospheric forcing was the same as in Sheffield et al. (2006) except for monthly precipitation. In Sheffield et al. (2006), the 3-hourly precipitation is hybridized to match the monthly observation from the Climatic Research Unit (CRU), whereas here the 3-hourly precipitation from Sheffield et al. (2006) was hybridized to match the monthly value from the Global Precipitation Climatology Centre's (GPCC) Full Data Product, version 4 (available online at http://www.dwd.de). As shown by Decharme and Douville (2006b), the GPCC precipitation certainly appears to be the best product for global hydrological applications.

The land surface parameters were specified according to the 1-km resolution Ecoclimap database developed at Météo-France (Masson et al. 2003). The soil textural properties were given by the Food and Agricultural Organization map at $10-\mathrm{km}$ resolution. Vegetation parameters were defined using two vegetation datasets: the Coordination of Information on the Environment (CORINE) land cover archive at 250-m resolution over Europe and the University of Maryland (Hansen et al. 2000) dataset at $1 \mathrm{~km}$ elsewhere. The mean gridcell elevation was specified according to the global 30 arc-second resolution (GTOPO30) dataset (available online at http:// eros.usgs.gov/\#/Find_Data/Products_and_Data_Available/ gtopo30_info). Lastly, the topographic indices used by TOPMODEL were given at a $1-\mathrm{km}$ resolution using the HYDRO1K dataset (available online at http://eros.usgs. gov/\#/Find_Data/Products_and_Data_Available/gtopo30/ hydro).

\section{b. Validation datasets}

GRACE provides monthly TWS variation estimates based on highly accurate maps of the earth's gravity field at monthly intervals over spatial scales of about 300400-km resolution (Wahr et al. 2004; Swenson et al. 2003). The instrumentation and onboard instrument processing units are described in detail in Haines et al. (2003). Here, we used 51 months (from August 2002 to December 2006, excluding June 2003 and January 2004 products because they are not available) of the Release 04 data produced by the Center for Space Research (CSR at The University of Texas at Austin) and Release 4.1 data produced by the Jet Propulsion Laboratory (JPL), and 49 months (September and December 2002, June 2003, and January 2004 products are not available) of the GeoForschungsZentrum (GFZ) Release 04. In this entire study, ISBA-TRIP TWS variations are compared to the mean and the standard deviation (STD) of the three GRACE product datasets. Because of the instrument, a few days of GRACE data were not used to generate the monthly time series since, to obtain comparable conditions, the ISBA-TRIP TWS monthly results were generated using the same dates as GRACE (for more details concerning GRACE data are available online at http://grace.jpl.nasa.gov/data/). 
TABLE 1. River basins used for the comparison between simulated and observed discharges. The name, drainage area, location, and the observation period of each station are also shown.

\begin{tabular}{|c|c|c|c|c|c|}
\hline Basins & Downstream station & Area $\left(\mathrm{km}^{2}\right)$ & Lat $\left({ }^{\circ} \mathrm{N}\right)$ & Lon $\left({ }^{\circ} \mathrm{E}\right)$ & Period \\
\hline Rio Amazonas & Obidos & 4758000 & -2.5 & -55.5 & 1986-2006 \\
\hline Congo & Brazzaville & 3649000 & -4.5 & 15.5 & 1986-2002 \\
\hline Mississippi & Vicksburg & 3011000 & 32.5 & -91.5 & $1986-95$ \\
\hline $\mathrm{Ob}$ & Salekhard & 2902000 & 66.5 & 66.5 & $1986-2000$ \\
\hline Parana & Timbues & 2596000 & -32.5 & -60.5 & $1986-94$ \\
\hline Yenisei & Ygarka & 2502000 & 67.5 & 86.5 & $1986-2000$ \\
\hline Lena & Kusur & 2310000 & 70.5 & 127.5 & $1986-2000$ \\
\hline Mackenzie & Mackenzie & 1736000 & 67.5 & -133.5 & $1986-2000$ \\
\hline Amur & Komsomolsk & 1772000 & 50.5 & 137.5 & $1986-90$ \\
\hline Volga & Volvograd & 1326000 & 48.5 & 44.5 & $1986-90$ \\
\hline Ganges & Harding Bridge & 970000 & 24.5 & 88.5 & $1986-92$ \\
\hline Yukon & Pilot station & 826000 & 61.5 & -162.5 & $1986-2000$ \\
\hline Orinoco & Puentes Angostura & 820000 & 8.5 & -63.5 & $1986-90$ \\
\hline Niger & Niamey & 799000 & 13.5 & 2.5 & $1986-90$ \\
\hline Danube & Ceatal Izmail & 797000 & 45.5 & 28.5 & $1986-90$ \\
\hline Columbia & The Dalles & 634000 & 45.5 & -121.5 & $1986-95$ \\
\hline Chari & Ndjamena & 558000 & 11.5 & 15.5 & $1986-91$ \\
\hline Kolyma & Kolymskoye & 536000 & 68.5 & 158.5 & 1986-2000 \\
\hline Brahmaputra & Bahadurabad & 519000 & 25.5 & 89.5 & $1986-92$ \\
\hline Soa Francisco & Juazeiro & 488000 & -9.5 & -40.5 & $1986-94$ \\
\hline Mékong & Mukdahan & 405000 & 16.5 & 104.5 & $1986-93$ \\
\hline Severnaya Dvina & Ust Pinega & 364000 & 64.5 & 41.5 & 1986-2000 \\
\hline Pechora & Oksino & 298000 & 67.5 & 52.5 & $1986-2000$ \\
\hline Indigirka & Vorontsovo & 277000 & 69.5 & 147.5 & 1986-94 \\
\hline Sénégal & Kayes & 239000 & 14.5 & -12.5 & $1986-90$ \\
\hline Yana & Ubileynaya & 228000 & 70.5 & 136.5 & $1986-2000$ \\
\hline Fraser & Hope & 211000 & 49.5 & -121.5 & $1986-95$ \\
\hline Wisla & Tczew & 194000 & 53.5 & 18.5 & $1986-94$ \\
\hline Rhin & Rees & 146000 & 51.5 & 6.5 & $1986-95$ \\
\hline Albany & Near Hat Island & 140000 & 51.5 & -83.5 & $1986-95$ \\
\hline Burdekin & Clare & 126000 & -20.5 & 147.5 & $1986-94$ \\
\hline Colorado & Wharton & 105000 & 29.5 & -96.5 & $1986-95$ \\
\hline Odra & Gozdowice & 100000 & 52.5 & 14.5 & $1986-94$ \\
\hline
\end{tabular}

A number of gauging station measurements covering the evaluation period (1986-2006) are available from the Global Runoff Data Center (GRDC, available online at http://www.grdc.sr.unh.edu/index.html), the R-ArcticNET database (University of New Hampshire, available online at http://www.r-arcticnet.sr.unh.edu/v3.0/ index.html) for high-latitude basins, and the Hydrology and Geodynamics of the Amazonian basin (HYBAM) dataset (available online at http://www.mpl.ird.fr/hybam/) for the Rio-Amazonas basin. However, records were not kept over identical periods for all the basins, as noted in Table 1.

Lastly, to evaluate the snowmelt timing simulated by ISBA over high-latitude basins, which is highly correlated with the springtime peak discharge (Decharme and Douville 2007), the simulated snow cover extent was compared with satellite observations from the National Snow and Ice Data Center (NSIDC, available online at http://nsidc.org/). This snow cover product overlaps the whole 1986-2006 period, on a monthly time scale, and at a $1^{\circ} \times 1^{\circ}$ horizontal resolution

\section{Results}

Figure 1 shows the spatial distribution of the climatological TWS simulated by ISBA-TRIP and estimated by GRACE over the same period (August 2002-December 2006). For a fair comparison of the integration of water storage variations, TWS must be treated in the same way as the GRACE data (Güntner 2009). While filtering is necessary to reduce noise in the GRACE data and to extract area-average storage change for a region of interest, several studies have shown that filtering may modify the signal. In particular for most hydrological applications, filtering has a smoothing effect that reduces the seasonal amplitude of the final TWS signal (Chen et al. 2007; Klees et al. 2007). Without corrections for this bias, it is not possible to evaluate hydrologic models 
(a) ISBA
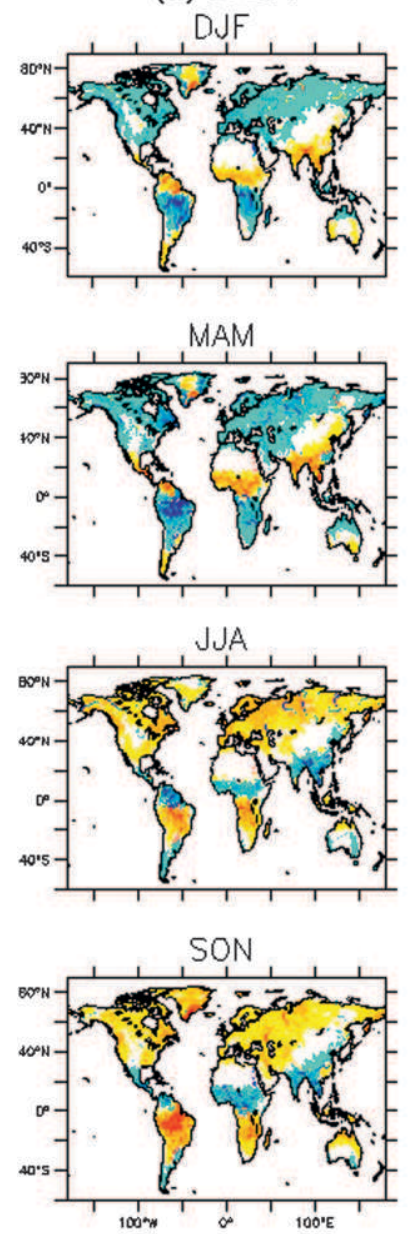

(b) Smoothed ISBA
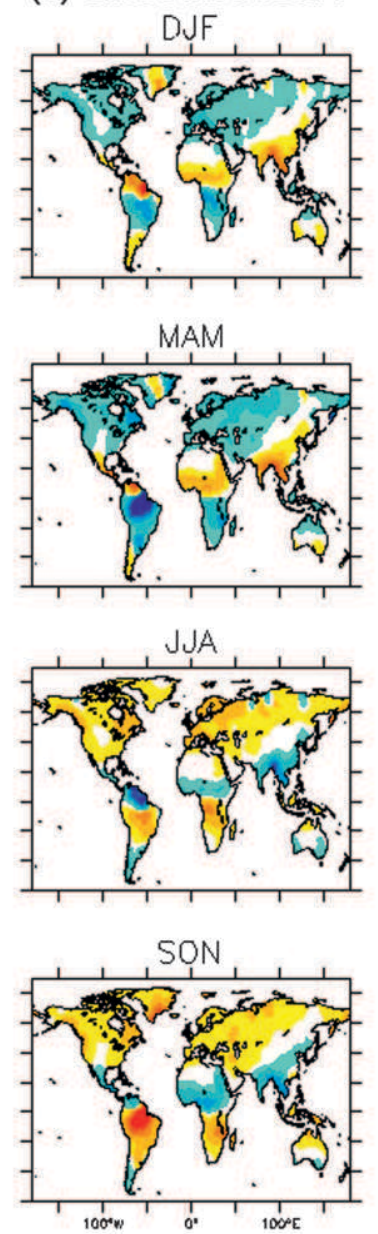

(c) GRACE
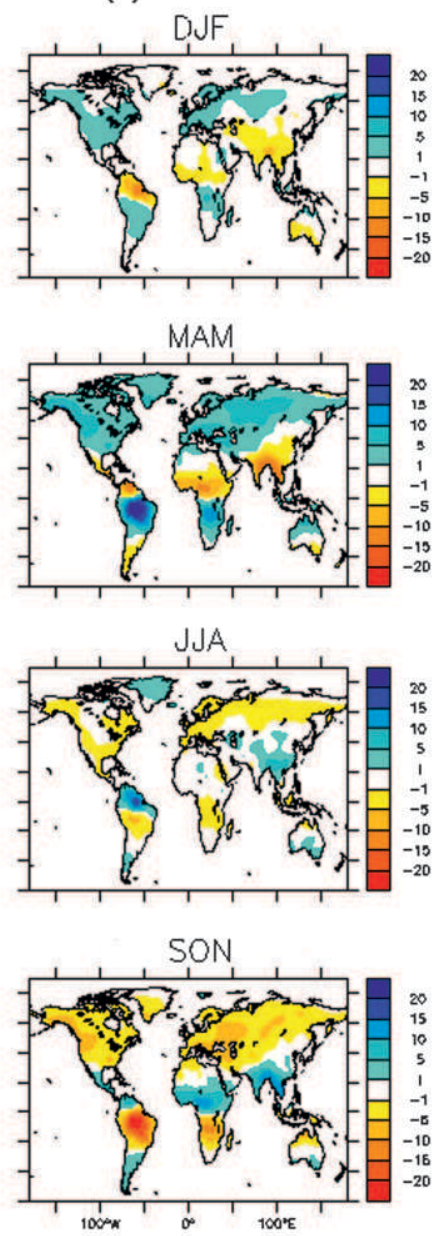

(d) zonal average
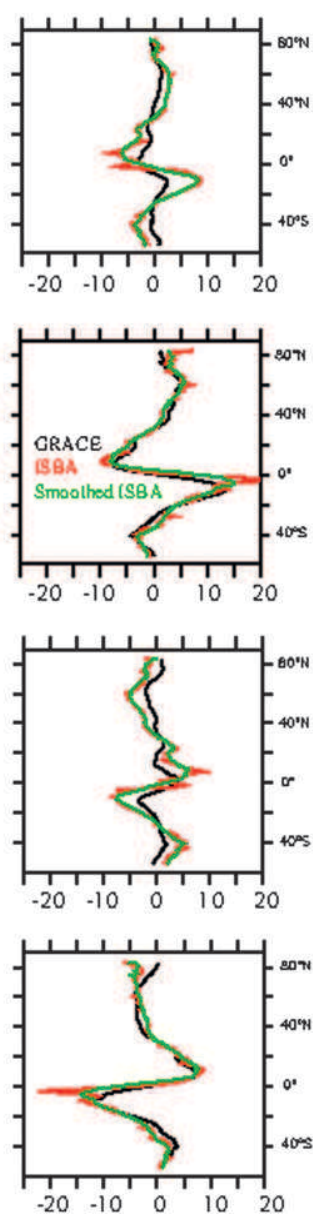

FIG. 1. Climatological comparison of (a) unsmoothed and (b) smoothed total TWS (cm) and (c) the mean GRACE product for (top to bottom) DJF, MAM, JJA, and SON. (d) The zonal average of each TWS product: GRACE (black), and ISBA-TRIP unsmoothed (red) and smoothed (green).

using GRACE. Therefore, ISBA-TRIP results were smoothed using the same GRACE averaging Gaussian filter of 500-km function as in Chambers (2006). The unsmoothed TWS is shown in the first column (a) of Fig. 1, and the smoothed and GRACE results in the second (b) and third (c) columns, respectively. Comparison between the smoothed and unsmoothed results shows that although the maximum amplitudes of TWS are explained by the stream river water content (column a), this information is partially lost with the smoothing method (column b). Except for the Sahel region in June-August (JJA), where TWS is overestimated, the pattern of the spatial seasonal mean variation of TWS is in good agreement with those estimated by GRACE. Nevertheless, relatively larger amplitudes over December-February (DJF) and JJA appear in ISBA-TRIP. This is confirmed by the fourth column (d) in Fig. 1, which represents the zonal average of TWS and GRACE.
Figure 2 gives the difference between the smoothed results and the average GRACE estimates (2002-06 average). It shows that the simulated signal amplitude during DJF and JJA is generally overestimated (Figs. 2a and 2c). In contrast, in Central America, Patagonia, South Asia, the Sahel, and regions around the mouths of some Arctic rivers-such as the Ob, Yenisei, Lena (Siberia) and Mackenzie (west Canada) - TWS is underestimated. During March-May [MAM; or September-November (SON)], the maximum bias is observed over the Amazon region (Figs. $2 \mathrm{~b}$ or $2 \mathrm{~d}$ ), where the maximum (or minimum) of the simulated TWS is shifted $5^{\circ}$ to the north compared to GRACE (Fig. 1). This induces a large dipole anomaly over this region. As shown in Figs. 2e and 2f, the temporal correlation and root-mean-square error (RMSE) between simulated TWS and GRACE over the same 51-month period perform relatively well. In terms of correlation, some discrepancies occur over desert 

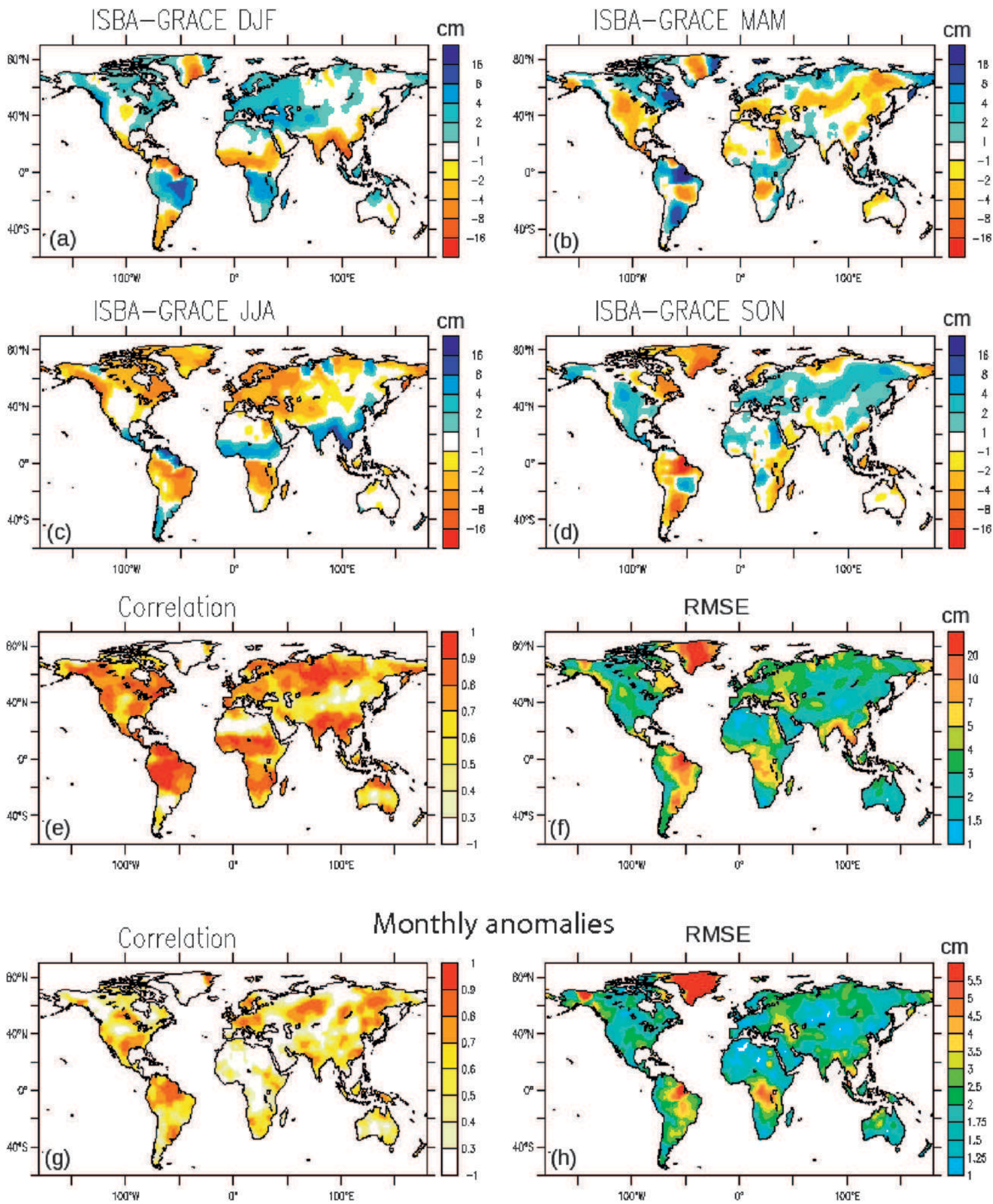

FIG. 2. Climatological biases between TWS $(\mathrm{cm})$ inferred from the smoothed ISBA-TRIP and the mean GRACE product for (a) DJF

(b) MAM, (c) JJA, and (d) SON. (e) The monthly correlation and (f) RMSE calculated over (g) the whole GRACE period and (h) monthly anomalies. 
areas and Greenland, while the maximum RMSE is located over Southeast Asia (Mekong, Ganges), Central Africa (Congo basin), South America (Amazon, Parana), and Greenland. In terms of interannual monthly anomalies (Figs. $2 \mathrm{~g}$ and 2h), the RMSE and the correlation show the same patterns but with lower correlation compared to the entire smoothed signal.

Figure 3 compares simulated smoothed and GRACE basin-averaged TWS annual cycles and monthly anomalies over the largest river basins listed in Table 1. Annual cycles of all TWS terms [Eq. (2), except $W_{r}$ because it is negligible] are also represented. Note that the temporal correlation $r$ and RMSE given on the annual cycle panels are calculated over the whole GRACE period. In addition, these statistics are compiled over the 183 largest river basins present in the TRIP hydrologic network and shown in Fig. 4. Over tropical basins (Amazon, Parana, Mekong, Ganges, Congo, Niger), TWS appears well correlated with the GRACE data ( $r$ higher than 0.8 for all basins except for Congo, where $r=0.63$ ). Nevertheless, the TWS annual cycle underestimates the minimum and overestimates the maximum GRACE values. Approximately one-half of TWS is explained by changes in soil moisture and the other half by stream water content variations. The monthly anomalies are appreciably reproduced except for the Congo. Over temperate basins (Mississippi, United States; Danube, Europe), the monthly anomalies are also well reproduced, although some defects appear in the simulated annual cycles. Over the Mississippi, the simulated seasonal amplitude is underestimated, whereas over the Danube, the annual cycle is two months earlier than GRACE. The dominant signal is attributed to soil moisture even though changes in snow mass during winter and river water content during the melting period (spring) are nonnegligible. Lastly, over boreal river basins (Mackenzie, Ob, Yenisei, Lena), the snow mass and the river water content play a major role. Snow is accumulated during winter and almost fully melted during summer. This induces maximum TWS in April for the warmer river basins $(\mathrm{Ob}$ and Mackenzie), and in May for the colder river basins (Yenisei and Lena). The annual cycles appear well simulated except over the Lena, where the simulated seasonal amplitude is underestimated. Over the $\mathrm{Ob}$, the monthly anomalies are well reproduced but, over other basins, the amplitudes of these anomalies are generally underestimated.

Figure 4 summarizes basin-scale comparisons between simulated TWS and GRACE data using the time correlation (Fig. 4a), the RMSE (Fig. 4b), and the timeaveraged STD (Fig. 4c) between the three GRACE products, which gives an estimation of GRACE uncertainties. The RMSE between ISBA-TRIP and GRACE is larger over South America, Africa, Europe, and South Asia than over other regions. The GRACE STD depends on latitude and increases from the poles to low latitudes, which is exactly what was seen by Wahr et al. (2006). Also, it increases with decreasing size of the river basin because of leakage effects as suggested by Seo et al. (2006). The simulated RMSE is generally larger than the weak GRACE STD, which underlines the relatively small uncertainties in GRACE data over major basins. However, the GRACE STD is generally larger over each of the small-to-medium-scale river basins than over major basins.

Figure 5 compares the monthly anomalies and the annual cycles of the simulated and observed discharges over the same 12 river basins as in Fig. 3. The simulated annual runoff is evaluated using the annual discharge ratio criterion Ratio $=\overline{Q_{\text {sim }}} / \overline{Q_{\text {obs }}}$, while the RMSE, the correlation $r$, and the efficiency Eff (Nash and Sutcliffe 1970) criteria measure the model's ability to capture the monthly discharge dynamics. This skill score is defined as follows:

$$
\text { Eff }=1.0-\frac{\sum\left[Q_{\text {sim }}(i)-Q_{\mathrm{obs}}(i)\right]^{2}}{\sum\left[Q_{\mathrm{obs}}(i)-\overline{Q_{\mathrm{obs}}}\right]^{2}},
$$

where $\overline{Q_{\text {obs }}}$ represents the observed temporal mean. The efficiency Eff can be negative if the simulated discharge is very poor and is above 0.5 for a reasonable simulation.

Over tropical basins, the statistics show that the Amazon, Mekong, and Ganges basins are well simulated, whereas the Parana, Congo and Niger basins appear drastically overestimated. Over temperate basins, the monthly anomalies are acceptably reproduced. The mean annual cycles of the Mississippi and Danube are reasonably well simulated, but the Mississippi shows a slight overestimation during the spring, as does the Danube basin during winter and spring. Over Arctic rivers, for the $\mathrm{Ob}$ and Mackenzie basins, both monthly anomalies and annual cycles are acceptably reproduced even though a slight overestimation appears in June or July. Colder basins (Yenisei and Lena) show a significant underestimation during the springtime peak period and monthly anomalies are poorly simulated. In addition, over these regions, a delay is generally observed between the simulated and observed springtime peak of discharge. The good comparison between simulated and observed mean annual cycles of snow cover extent given in Fig. 6 shows that the snowmelt timing is not the cause of this delay.

Lastly, Fig. 7 summarizes the comparisons between simulated and observed river discharges using statistics compiled over the downstream stations of each basin given in Table 1. The good correlations (Fig. 7a) confirm 

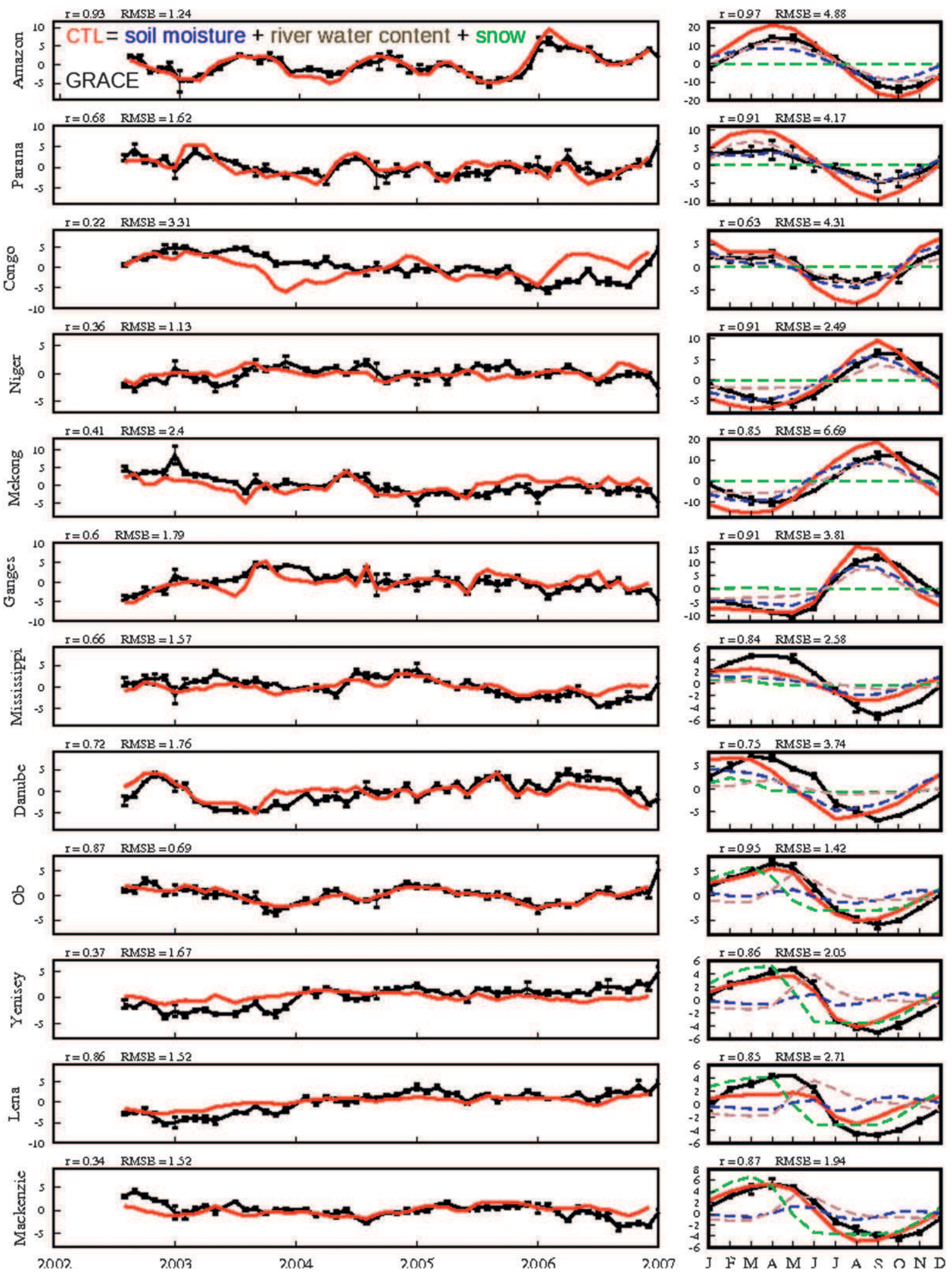

FIG. 3. Basin-scale comparison ( $\mathrm{cm}$ ) between the (right) mean annual cycle and (left) monthly anomalies of smoothed ISBA-TRIP TWS (red) and the mean GRACE product with its associated STD (black). Annual cycles of each TWS component, except vegetation interception, are also shown: total soil moisture (blue), snow water equivalent (green), and stream river water content (brown). Note that RMSE and $r$ shown above the annual cycle panels are calculated over the whole GRACE period. 

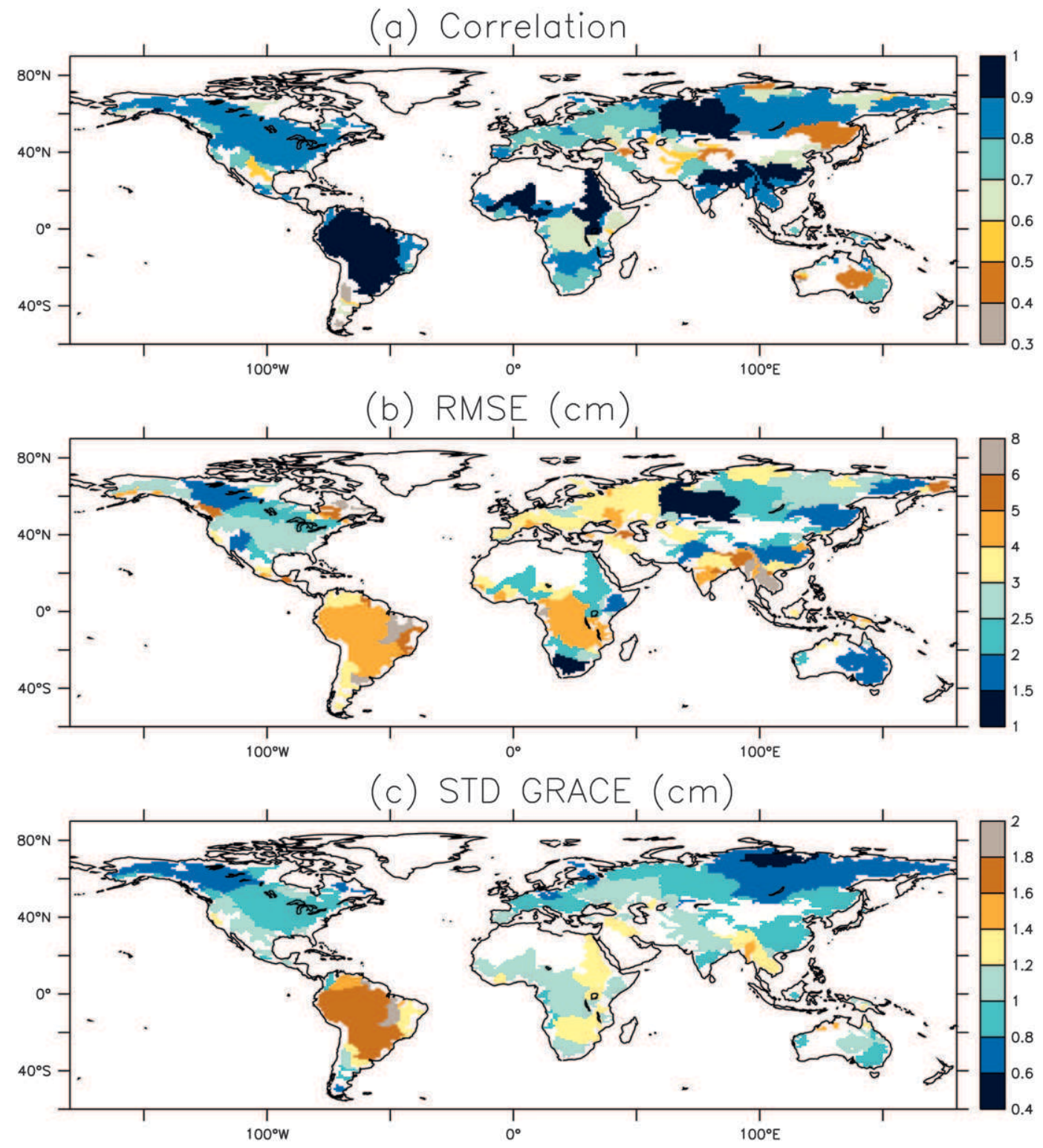

FIG. 4. Statistical comparison between TWS inferred from ISBA-TRIP and GRACE over the largest river basins of the world: (a) correlation, (b) RMSE, (c) STD between the three GRACE products used in this study.

that the model captures the observed time variability while the RMS and Ratio (Figs. 7b and 7c) show some large deficiencies. A drastic overestimation appears over the majority of tropical basins, which is confirmed by the highest RMS values, while this overestimation is smaller for temperate basins. Conversely, the statistics confirm that the river discharges of Arctic basins and especially East Siberian basins are generally underestimated. The efficiency coefficient (Fig. 7c) reinforces these remarks: it is small for the overestimated tropical basins and for the Arctic basins with underestimated and delayed springtime peak.

\section{Discussion}

In general terms, the simulated TWS using ISBATRIP compares well with GRACE data even though some differences appear throughout the comparison shown in section 4. Except for boreal regions, the seasonal cycle of the simulated TWS seems to be relatively larger than in GRACE data (overestimate of the maximum, underestimate of the minimum values), especially over tropical regions like South America and central Africa. This can be attributed to the water river content term, which makes an important contribution to the 

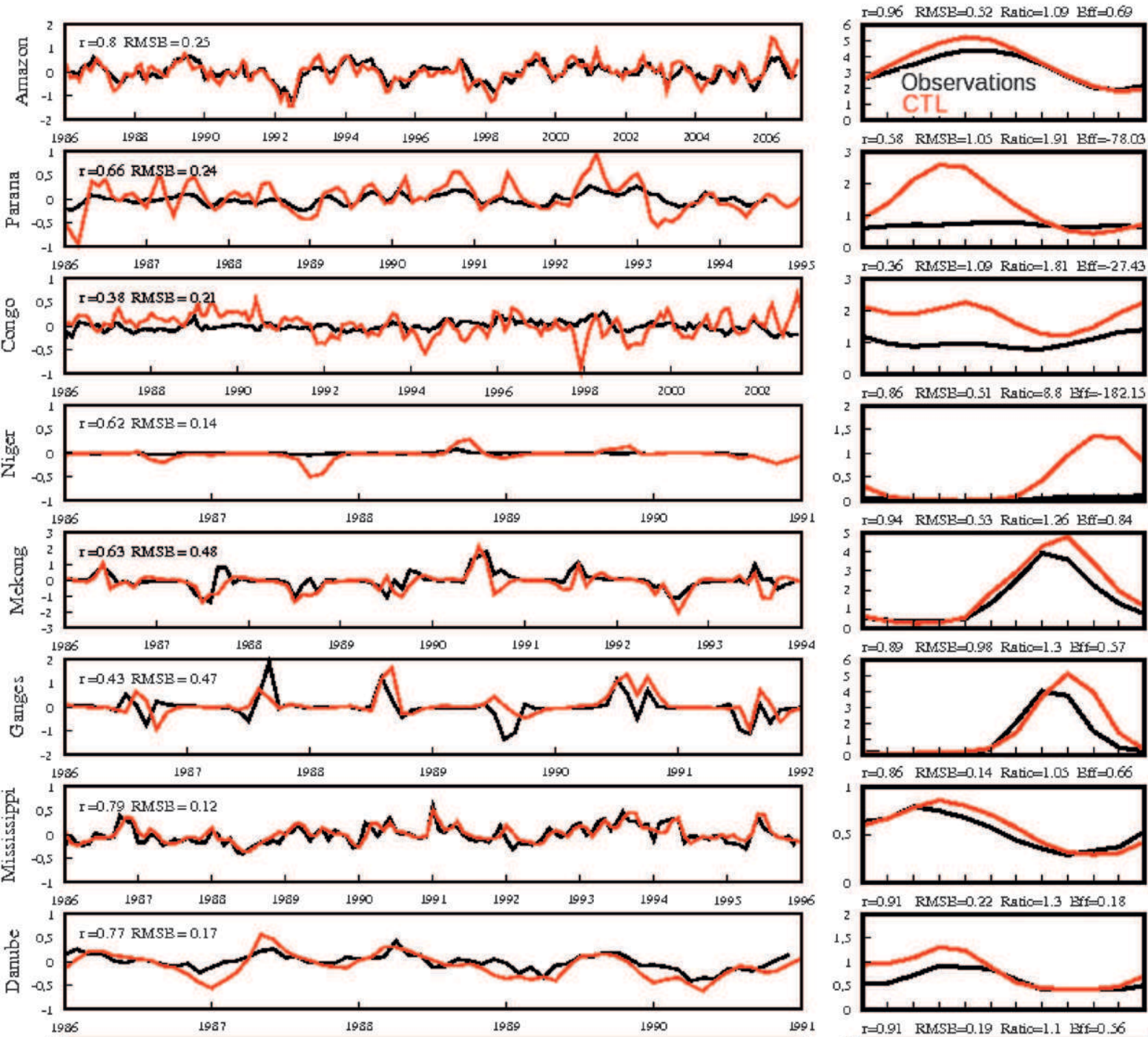

1988
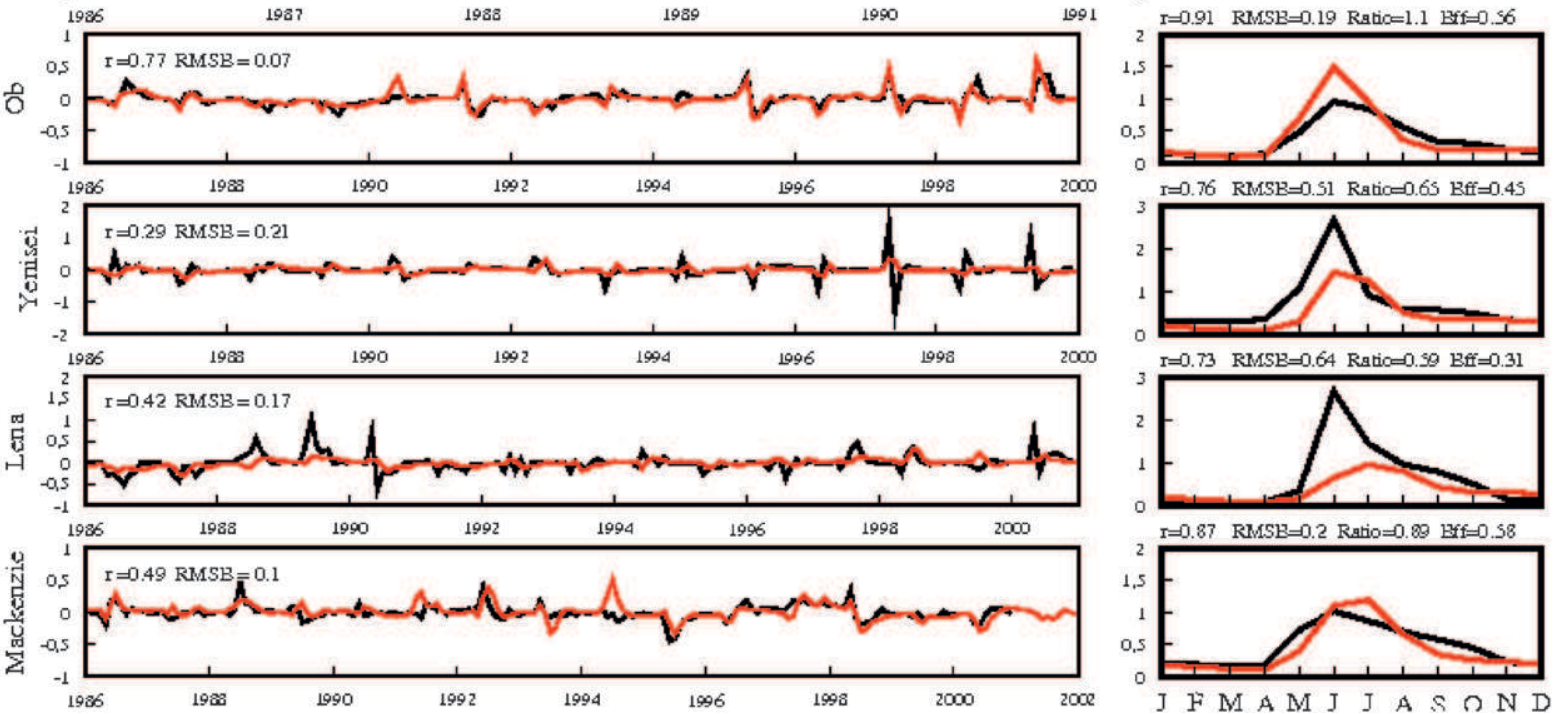

FIG. 5. Basin-scale comparisons ( $\mathrm{mm} \mathrm{day}^{-1}$ ) between the (right) annual cycle and (left) monthly-mean anomalies of simulated (red) and observed (black) discharges. Statistics shown above the annual cycle panels are calculated over the observation periods given in Table 1. 
$\mathrm{Ob}$

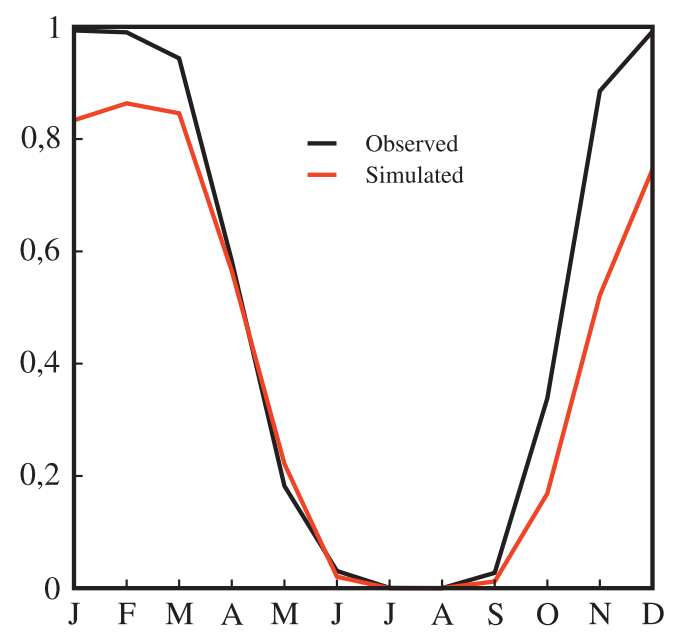

Lena

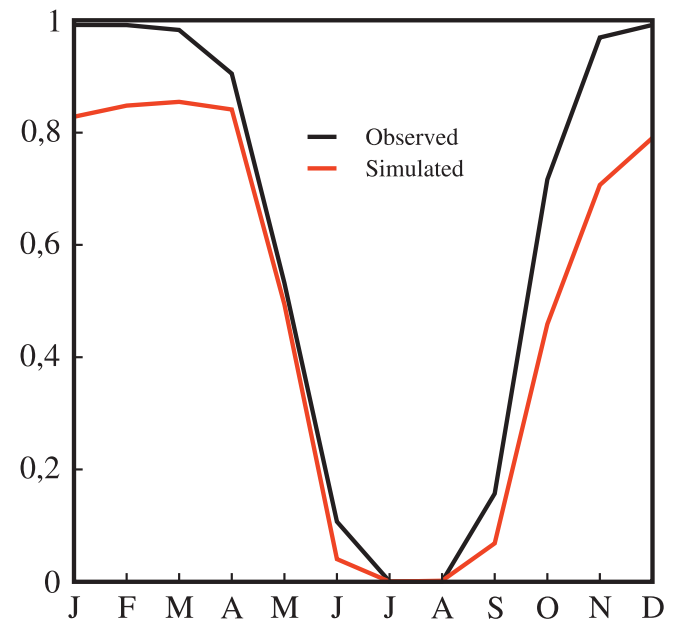

Yenisei

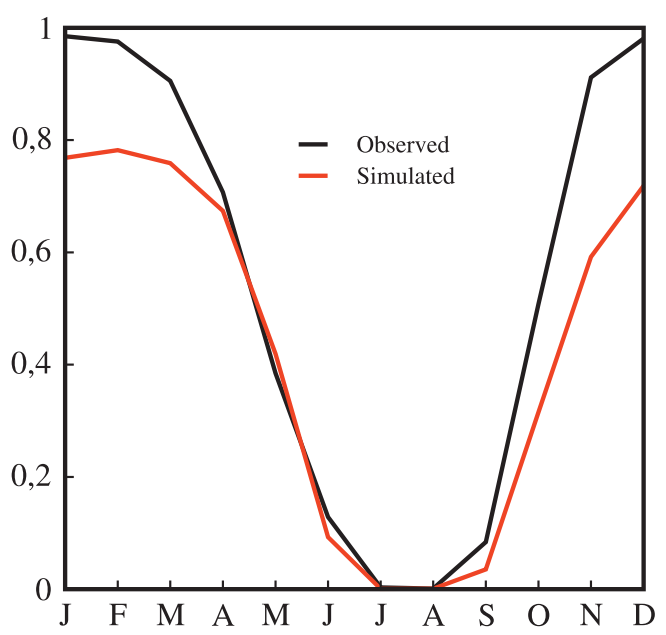

Mackenzie

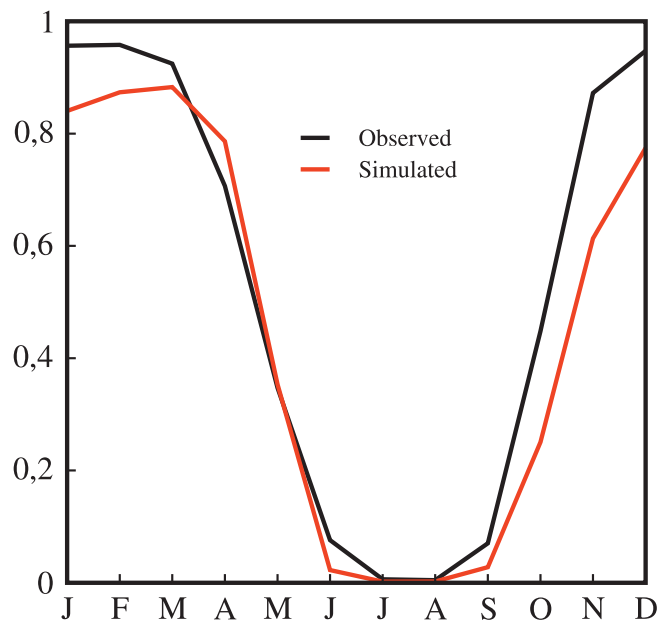

FIG. 6. Comparison between simulated and observed mean annual cycles of snow cover extent over high-latitude basins (expressed in fraction of each basin area).

simulated TWS over all regions as shown in Fig. 3. The evaporation calculated by ISBA-TRIP is another source of errors. In addition, GRACE products are highly uncertain over desert areas. Here, TWS change is always under $1 \mathrm{~cm}$ in magnitude (Fig. 1), which is approximately the accuracy of GRACE measurement (Chambers 2006). Over ice sheet regions like Greenland, the large differences are mainly due to the nonrepresentation of glacier processes in ISBA (snow/firn/ice metamorphism and icerunoff dynamics). Snow is only accumulated and rarely melted in the model, which explains the poor representation of the ice cap seasonal cycle. As a result, the correlation is poor and the error is high over these regions.

For the river discharge comparisons, the results are globally satisfactory but some important differences appear, such as the general overestimation of simulated streamflow (except over boreal regions). Besides uncertainties in the atmospheric forcing, especially precipitation that plays a major role in simulating realistic river discharge (Decharme and Douville 2006b), and in regard to Eq. (1), this could be due to the underestimation of continental evaporation, which could be directly related to missing processes, such as evaporation at the potential rate over saturated areas (marshes, ponds), irrigation, flooding, and river management (Hanasaki et al. 2006; Sacks et al. 2008; Decharme and Douville 2007). These neglected processes can induce large errors, especially over semiarid regions. As shown in Fig. 8, the main error of the simulated TWS over the Mississippi River basin matches the driest Mississippi region (western 

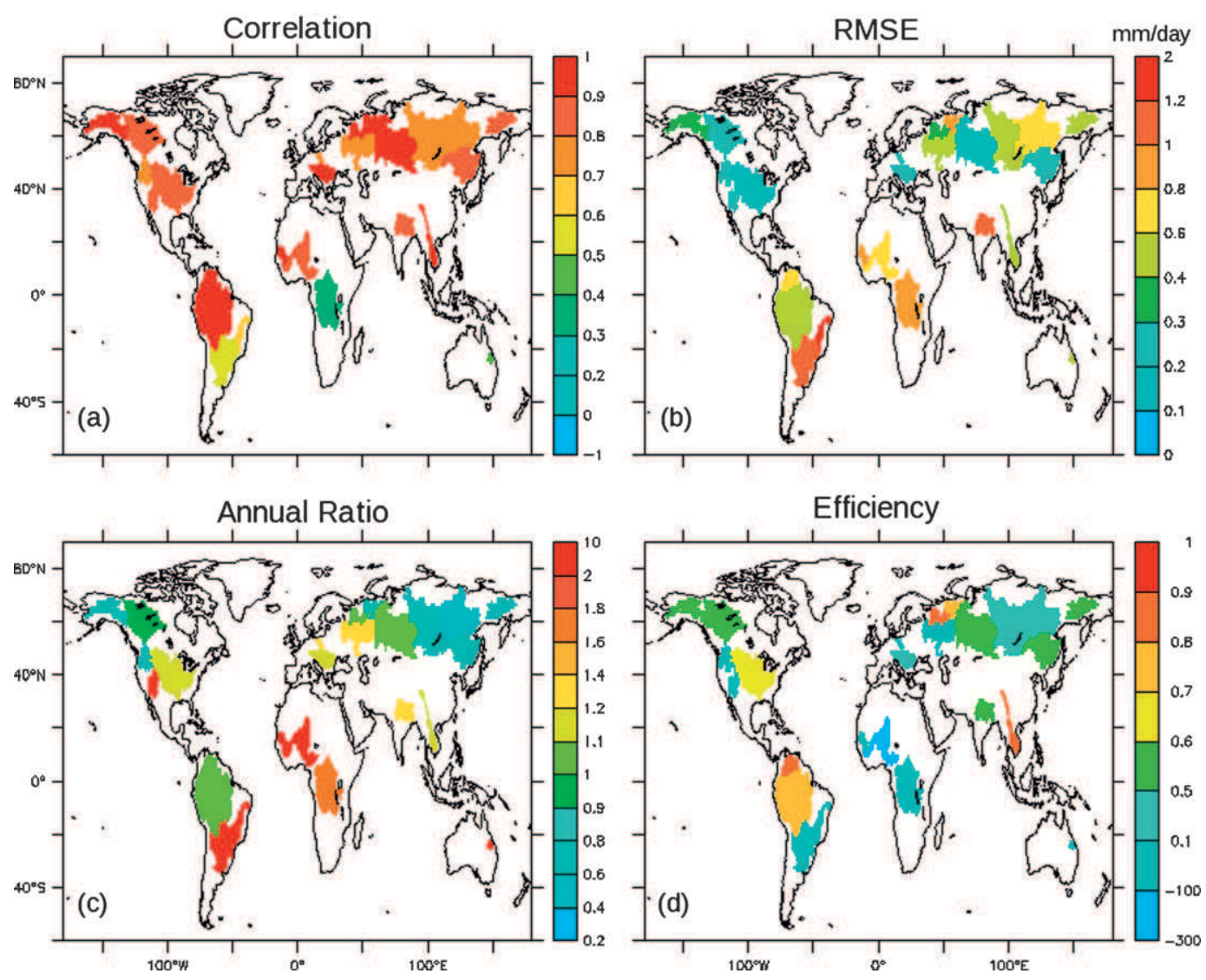

FIG. 7. Statistical comparison between simulated and observed discharge at each of the 34 gauge stations of Table 1: (a) correlation, (b) RMSE, (c) annual ratio, (d) and efficiency.

$95^{\circ} \mathrm{W}$ ), where irrigation is intensive. The worst RMSE and correlation (Figs. 8a and $8 \mathrm{~b}$ ) between the simulated and observed TWS are found near the Oahe Dam $\left(44^{\circ} \mathrm{N}\right.$, $\left.100^{\circ} \mathrm{W}\right)$. The water body stored upstream of the dam represent an area of $620 \mathrm{~km}^{2}$ and a drainage area of $\sim 625000 \mathrm{~km}^{2}$. Oahe Dam stores water during winter, and the intensive irrigation reduces this storage via an increase in spring/summer evaporation. ISBA-TRIP neglects these two processes and then underestimates the amplitude of the TWS seasonal cycle over the western Mississippi basin compared to GRACE (Fig. 8c). Another consequence of neglecting irrigation and dams can be observed at the Hermann station located on the western part of the Mississippi River (Fig. 8e). The simulated annual discharge is significantly overestimated by $\sim 30 \%$ ( $0.23 \mathrm{~mm}$ day $^{-1}$ simulated against $0.18 \mathrm{~mm}$ day $^{-1}$ observed). The Mississippi basin is well documented in terms of rain gauge density and uncertainties in precipitation forcing only cannot explain this significant overestimation (Decharme and Douville 2006b). Deficiencies in the model's runoff parameterization could be the main causes but the eastern part of the Mississippi is well simulated, as shown by the good TWS RMSE and correlation compared to GRACE (Figs. 8a and b). The simulation of the TWS seasonal cycle is acceptable (Fig. 8d), and discharges at the Metropolis station are well simulated (Fig. 8f). The eastern part of the Mississippi is wetter than the western part and is probably less affected by human activities.

Over colder regions (east Siberia), the simulated discharge is underestimated. The main cause is likely to be the quality of the precipitation forcing, which is not optimum over these regions (Decharme and Douville 2006b). Because the snowmelt represents the major contribution to river discharge, if the snowfall is underestimated, the discharge will also be underestimated. However, the ISBA snow scheme may also contribute to this error because of the nonrepresentation of some processes, such as deep permafrost or river ice storage.

The simulation of TWS and discharge can be linked and discussed in more depth because river water storage represents an important component of the simulated TWS signal. However, the comparison of errors in TWS and discharge simulations is difficult for two reasons. 
(a)TWS RMSE (cm)

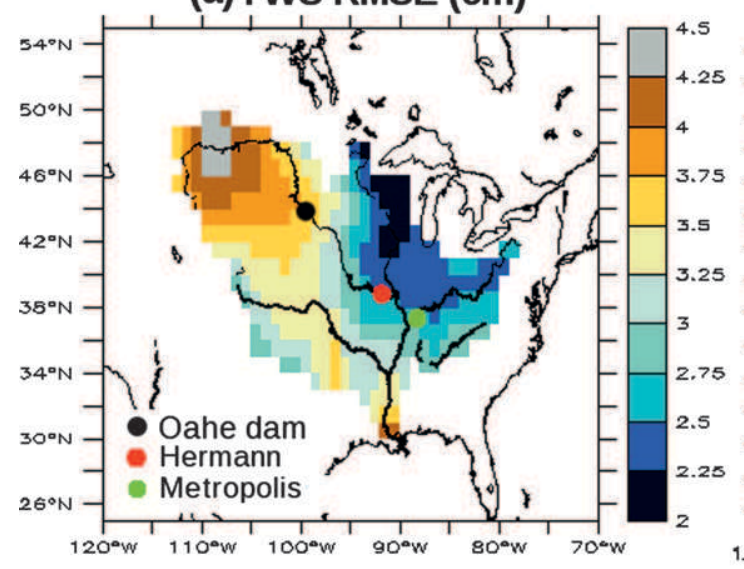

(c) TWS Western $95^{\circ} \mathrm{W}$

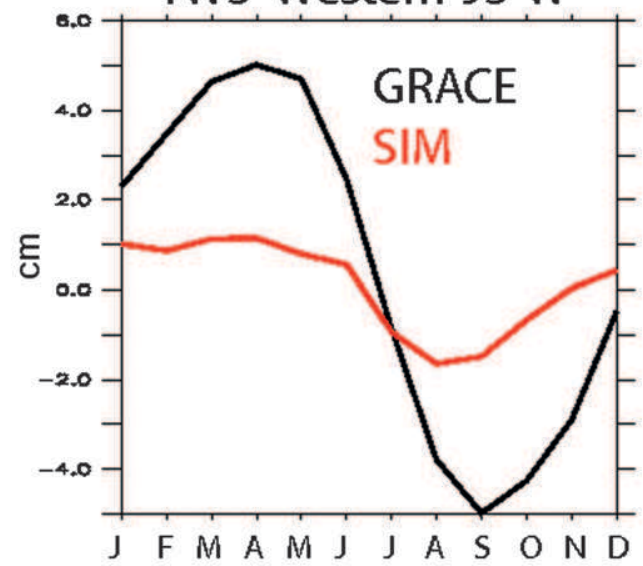

(e) Streamflow at Hermann

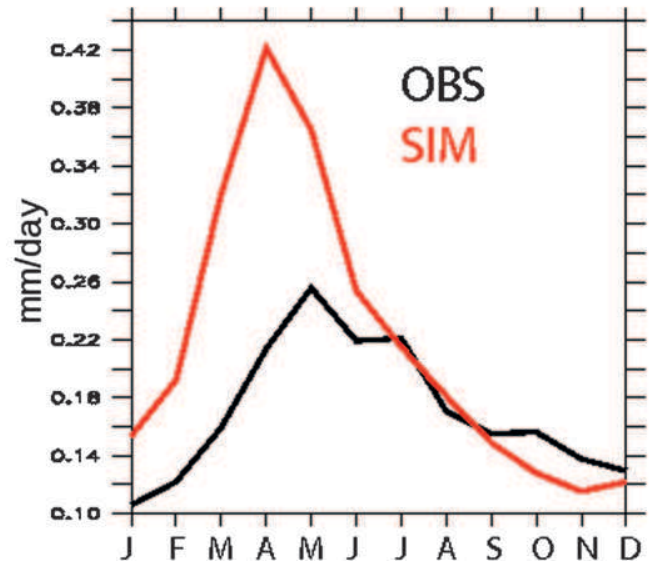

(b) TWS correlation

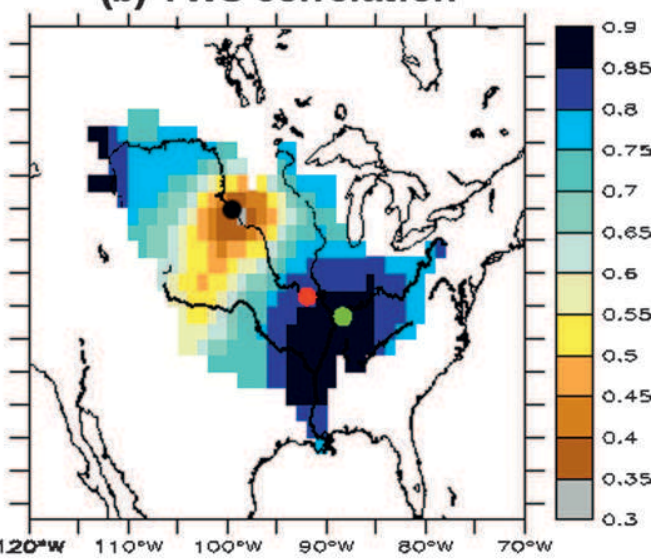

(d) TWS Eastern $95^{\circ} \mathrm{W}$

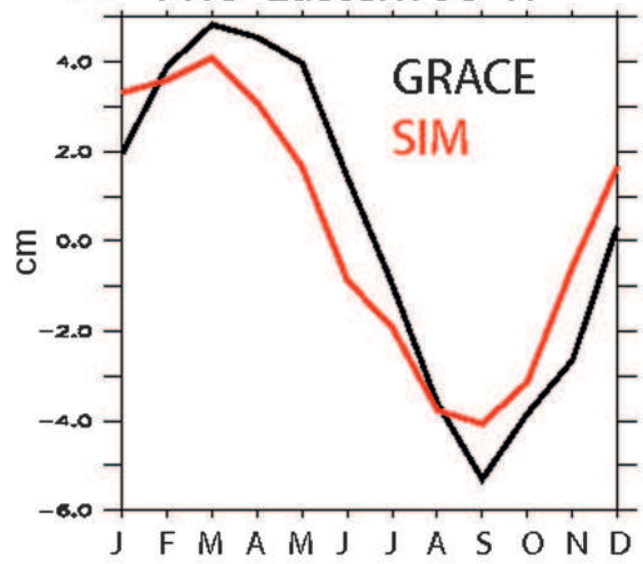

(f) Streamflow at Metropolis

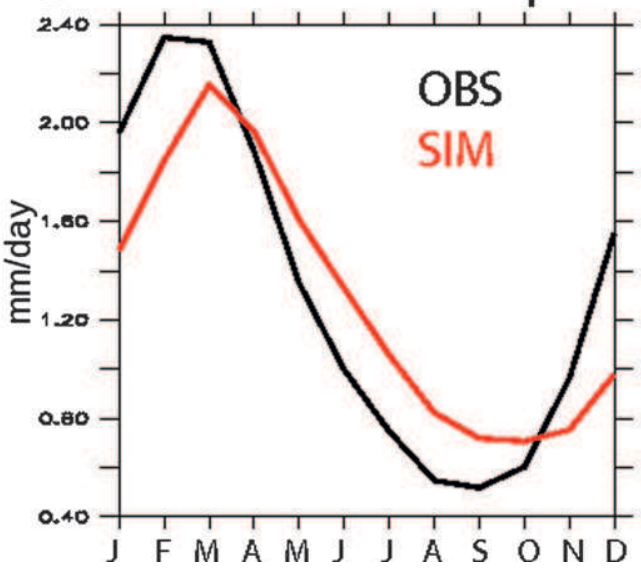

FIG. 8. Comparison between simulated and observed TWS over Mississippi River basin: (a) RMSE and (b) $r$. The simulated (red) and observed (black) TWS annual cycles averaged over the (c) western and (d) eastern part of the Mississippi using the $95^{\circ} \mathrm{W}$ parallel. Comparison of the simulated and observed discharges annual cycles at the (e) Hermann and (f) Metropolis stations located in the western and eastern parts of the basin, respectively. 

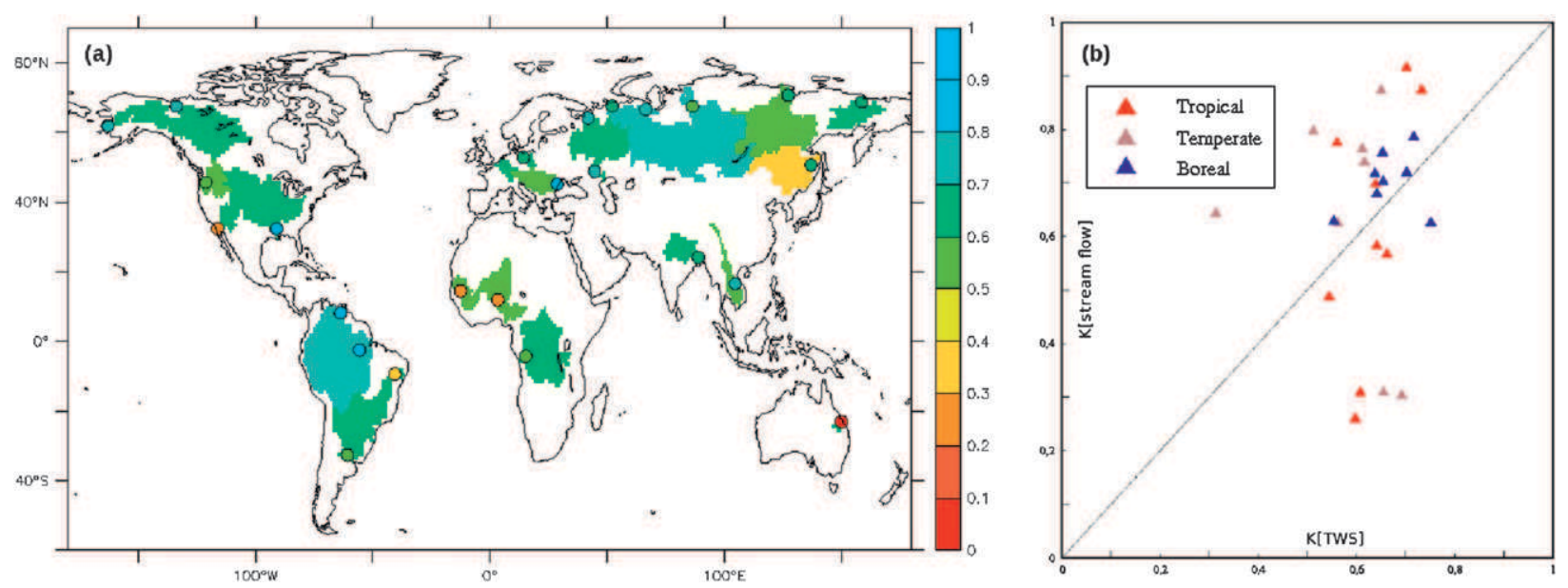

FIG. 9. (a) Basin-scale comparison between ISBA-TRIP/GRACE (K[TWS]) and ISBA-TRIP/in situ streamflow (K[streamflow]) climatological errors. Each downstream station is represented by a circle. The calculation of $K$ is described in section 5. (b) Scatterplot of $K$ [TWS] vs $K$ [streamflow] for selected river basins in three climatic zones (tropical, temperate, and boreal).

First, the GRACE data cover the period 2002-06, while streamflow data generally cover the period 1986-2000 (Table 1). Second, TWS is expressed in centimeters, while discharges are expressed in millimeters per day. The applied solution is to compare the performance of the model to reproduce the observed TWS and discharge on the mean annual cycles. In addition, the error in simulating both TWS and discharge must be

$$
\begin{aligned}
K[\text { streamflow }] & =\frac{1}{N_{\text {month }}} \sum_{i=1}^{N_{\text {month }}} k_{i} \text { with } \\
K[\text { TWS }] & =\frac{1}{N_{\text {month }}} \sum_{i=1}^{N_{\text {month }}} k_{i} \text { with }
\end{aligned}
$$

where $N_{\text {month }}$ is equal to 12 , that is, the number of months in an annual cycle. SIM $_{i}$ and $\mathrm{OBS}_{i}$ represent the simulated and the observed values (for TWS or discharge) at month $i$, respectively. In the TWS case, the signal varies around 0 , which can induce some numerical artifacts if a monthly value is close to 0 . So, a parameter, $m$, is introduced that represents the largest negative value between simulation and observation. The $m$ parameter brings out possible numerical artifacts and allows TWS to be represented as a positive signal. To sum up, $K$ measures the error between the simulated and the observed annual cycle for both TWS and discharge. Here $K$ is computed over the 34 river basins given in Table 1 . The spatial distribution and a scatterplot between $K$ [streamflow] and $K$ [TWS] is shown in Figs. 9a and $9 \mathrm{~b}$, respectively. normalized. To this end, Fig. 9 attempts to relate the combined model performance in simulating TWS and discharge via a normalized error criterion $K$ between simulation and observations. This criterion is calculated over the mean annual cycles for both discharge, $K$ [streamflow], and TWS, $K$ [TWS], and is normalized as follows between 0 , for a maximum error, and 1 , for a perfect model:

Over temperate basins, the error in simulating TWS is greater than in simulating discharges. However, this result is not observed over small arid basins (Colorado) or over the Rhine basin (Europe), which are significantly anthropized.

Over tropical basins, the spread of the $K$ [streamflow] error is significantly larger than the $K$ [TWS] error. The $K$ [streamflow] is about 0.9 for the Amazon and does not exceed 0.55 for the Parana Sao Francisco, Niger, and Senegal. Besides uncertainties in the precipitation forcing, this result indicates that the main error is due to the model physics. As shown in Figs. 5 and 7c, the large discharge overestimation simulated over basins such as the Parana, Sao Francisco, Niger, and Senegal is the main source of $K$ [streamflow] error. It is well known that CHSs tend to overestimate tropical discharges (Ngo-Duc et al. 
2005; Decharme and Douville 2007). This is generally due to the lack of representation of floodplain processes (Prigent et al. 2007; Decharme et al. 2008) that can enhance the simulated evaporation and, consequently, reduce the amplitude of the simulated discharges as well as the amplitude of the TWS seasonal cycle. Other processes that contribute to both the amplitude and phase of discharge and TWS are certainly the nonrepresentation of dams and groundwater. Dams can store large amounts of water before being used for irrigation (Hanasaki et al. 2006) and other purposes, while groundwater allows deep water storage for long periods before it returns to the surface water channel (Fan et al. 2007; Miguez-Macho et al. 2007; Part II).

Over boreal regions, the $K$ [TWS] error has the same order of magnitude as the $K$ [streamflow] error. For example, the Yenisei River and especially the Lena River in Figs. 3 and 5 indicate that the simulated streamflows are largely underestimated. This fact is clearly due to an underestimation of precipitation forcing (mainly snowfall). Consequently, the amplitude of the simulated TWS is reduced compared to the observed GRACE datasets. The simulated TWS is largely dominated by the contrast in snow mass and river water content between summer and winter. Indeed, boreal river water content is partially frozen during the winter, especially over cold regions. Increasing temperatures at the beginning of the summer induce the breaking up of ice and coincide with large discharge from snowmelt. At that time, the flow velocity can be significantly higher than $0.5 \mathrm{~m} . \mathrm{s}^{-1}$ (Kilmjaninov 2007). This could explain the high seasonal contrast between simulated and observed discharge and TWS at the mouths of boreal rivers. Figure 2 (ISBA-GRACE JJA) shows that the simulated TWS JJA is slightly underestimated over the largest boreal basins except at each river mouth, where it is overestimated. Because of the low flow velocity $\left(0.5 \mathrm{~ms}^{-1}\right)$, a part of the water is stored in the river instead of flowing into the Arctic Ocean. Note that, as shown in Fig. 6, the springtime snowmelt timing simulated by ISBA is not the reason for this problem.

\section{Conclusions}

This study focuses on the global evaluation of the ISBA-TRIP CHS using both GRACE TWS estimates and in situ streamflow measurements over large river basins. For this purpose, the simulation is performed in an offline mode using an improved 3-hourly time step atmospheric forcing dataset developed by Sheffield et al. (2006) at $1^{\circ} \times 1^{\circ}$ resolution. The TWS simulated by ISBA-TRIP is computed from snow mass, soil moisture, and water river content, while precipitation intercepted by the vegetation is neglected. The river discharge is computed by TRIP, directly fed with ISBA's runoff and drainage. In other words, a twofold constraint is used to evaluate two components out of four in the simulated surface water balance [Eq. (1)].

Former studies (Lettenmaier and Famiglietti 2006; Niu and Yang 2006; Swenson and Milly 2006; Ngo-Duc et al. 2007; Syed et al. 2007) have shown that GRACEderived TWS variations are useful for detecting missing compartments or improving existing ones in CHSs. The present study confirms this statement. GRACE uncertainties are relatively small over major basins and are globally lower than uncertainties on TWS simulation, which confirms that GRACE can be useful for evaluating CHSs. The GRACE uncertainties are also minimum in high latitudes where in situ hydrological measurements are generally very sparse. These are, therefore, the regions where GRACE can provide an efficient constraint for improving CHSs (e.g., Niu and Yang 2006). However, the use of three GRACE solutions suggest that the comparison with CHSs should be taken with caution over small-to-medium-scale river basins where uncertainties in GRACE data are higher than over major basins.

Globally speaking, the ISBA-TRIP modeling system satisfactorily reproduces the seasonal and interannual variability of TWS and discharge over large river basins. The main discrepancies are a general overestimation of annual river discharge and of the amplitude of annual TWS variations. The phase of the annual cycle also shows some systematic errors. In addition to uncertainties in both GRACE data and the atmospheric forcing, various model deficiencies can be invoked for such discrepancies.

- Several water storage compartments (i.e., dams, lakes, or groundwater storage) are not simulated in the ISBATRIP system. Kim et al. (2009) demonstrated that neglecting river storage may lead to a mismatch in the amplitude and phase of TWS seasonal variations compared to GRACE observations. Here, even taking river storage into account, simulated TWS shows a slight mismatch in the amplitude and phase. Neglected groundwater storage could be one of the sources of error. Such a hypothesis is partly investigated in Part II using sensitivity experiments with respect to the time of water storage in a simplified groundwater reservoir.

- At monthly-to-seasonal time scales, TRIP can contribute to systematic errors in the phase and amplitude, not only of river discharge but also of TWS variations. As in Kim et al. (2009), our results indeed confirm that the river reservoir is a significant component of TWS that cannot be neglected, at least when averaging the model outputs over large river basins. Over high-latitude basins, the lag between both simulated and observed 
TWS and discharge signals seems to indicate that the use of a constant flow velocity in TRIP is a broad approximation. Such a hypothesis is further investigated in Part II using experiments to investigate sensitivity to variable flow velocity.

- At annual-to-interannual time scales, TRIP is probably not the main source of error. The main deficiency in the simulation of TWS and discharge appears to be linked to an underestimation of continental evaporation. Over all basins (except in permafrost regions), annual discharge is overestimated. On the one hand, this may be again due to missing surface water reservoirs (i.e., marshes, ponds, irrigation, and floods), where surface evaporation occurs at a potential rate. On the other hand, the use of subgrid variability in land surface models can also contribute to increased runoff at the expense of surface evapotranspiration (Decharme and Douville 2007; Decharme 2007).

In summary, the present study confirms both the utility and limitations of GRACE measurements for the validation of CHSs. On the one hand, GRACE provides an additional constraint on the simulated hydrology and consolidates the former evaluation only based on river discharge observations. In addition, in situ discharge records do not exceed the end of the twentieth century, and GRACE data cover a more recent period, which allows model evaluation to be extended after 2002. On the other hand, the low-resolution, limited accuracy, and river contamination of the GRACE-derived TWS variations can limit a clear detection and attribution of model deficiencies. Sensitivity experiments (Part II) are therefore necessary to complement such analyses and improve the current generation of CHSs.

Acknowledgments. This work is supported by the CYMENT project of the RTRA STAE Toulouse, the Centre National de Recherches Météorologiques of Méteo-France, the Centre National de la Recherche Scientifique of the French research ministry, and the IMPACT BOREAL project of the French Agence Nationale de la Recherche. The authors wish to thank the GRACE, GRDC, R-ArcticNET, and HyBAm (especially Gerard Cochonneau) sampling teams for their field data collection effort. Thanks are also due to Aurélien Ribes (CNRM) and to the anonymous reviewers for their constructive comments.

\section{REFERENCES}

Alkama, M. R., M. Kageyama, G. Ramstein, O. Marti, P. Ribstein, and D. Swingedouw, 2008: Impact of a realistic river routing in coupled ocean-atmosphere simulations of the Last Glacial Maximum climate. Climate Dyn., 30, 855-869.
Beven, K. J., and M. J. Kirkby, 1979: A physically based, variable contributing area model of basin hydrology. Hydrol. Sci. Bull., 24, 43-69.

Boone, A., J.-C. Calvet, and J. Noilhan, 1999: Inclusion of a third soil layer in a land surface scheme using the force-restore method. J. Appl. Meteor., 38, 1611-1630.

Chambers, D. P., 2006: Observing seasonal steric sea level variations with GRACE and satellite altimetry. J. Geophys. Res. 111, C03010, doi:10.1029/2005JC002914.

Chen, J. L., C. R. Wilson, and B. D. Tapley, 2006: Satellite Gravity Measurements Confirm Accelerated Melting of Greenland Ice Sheet. Science, 313, 1958-1960.

,,-- J. S. Famiglietti, and M. Rodell, 2007: Attenuation effect on seasonal basin-scale water storage changes from GRACE time-variable gravity. J. Geod., 81, 237-245.

Crowley, J. W., J. X. Mitrovica, R. C. Bailey, M. E. Tamisiea, and J. L. Davis, 2006: Land water storage within the Congo Basin inferred from GRACE satellite gravity data. Geophys. Res. Lett., 33, L19402, doi:10.1029/2006GL027070.

Decharme, B., 2007: Influence of runoff parameterization on continental hydrology: Comparison between the Noah and the ISBA land surface models. J. Geophys. Res., 112, D19108, doi:10.1029/2007JD008463.

_ , and H. Douville, 2006a: Introduction of a sub-grid hydrology in the ISBA land surface model. Climate Dyn., 26, 65-78.

$\longrightarrow$, and - 2006b: Uncertainties in the GSWP-2 precipitation forcing and their impacts on regional and global hydrological simulations. Climate Dyn., 27, 695-713.

— and _ 2007: Global validation of the ISBA sub-grid hydrology. Climate Dyn., 29, 21-37.

,$- \ldots$, A. Boone, F. Habets, and J. Noilhan, 2006: Impact of an exponential profile of saturated hydraulic conductivity within the ISBA LSM: Simulations over the Rhône basin. J. Hydrometeor., 7, 61-80.

- $\longrightarrow$, C. Prigent, F. Papa, and F. Aires, 2008: A new river flooding scheme for global climate applications: Off-line evaluation over South America. J. Geophys. Res., 113, D11110, doi:10.1029/2007JD009376.

_ - R. Alkama, E. Douville, M. Becker, and A. Cazenave, 2010: Global evaluation of the ISBA-TRIP continental hydrological system. Part II: Uncertainties in river routing simulation related to flow velocity and groundwater storage. J. Hydrometeor., 11, 601-617.

Dirmeyer, P. A., 2000: Using a global soil wetness dataset to improve seasonal climate simulation. J. Climate, 13, 2900-2922.

_ 2001: Climate drift in a coupled land-atmosphere model. J. Hydrometeor., 2, 89-100.

Douville, H., 1998: Validation and sensitivity of the global hydrologic budget in stand-alone simulations with the ISBA land surface scheme. Climate Dyn., 14, 151-171.

_ 2003: Assessing the influence of soil moisture on seasonal climate variability with AGCMs. J. Hydrometeor., 4, 1044 1066.

_ 2004: Relevance of soil moisture for seasonal atmospheric predictions: Is it an initial value problem? Climate Dyn., 22, 429-446.

_ J.-F. Royer, and J.-F. Mahfouf, 1995: A new snow parameterization for the Météo-France climate model. Part 1: Validation in stand-alone experiments. Climate Dyn., 12, 21-35. , S. Planton, J.-F. Royer, D. B. Stephenson, S. Tyteca, L. Kergoat, S. Lafont, and R. A. Betts, 2000a: Importance of vegetation feedbacks in doubled- $\mathrm{CO}_{2}$ climate experiments. J. Geophys. Res., 105 (D11), 14 841-14 861. 
_ , P. Viterbo, J.-F. Mahfouf, and A. C. M. Beljaars, 2000b: Evaluation of the optimum interpolation and nudging techniques for soil moisture analysis using FIFE data. Mon. Wea. Rev., 128, 1733-1756.

Fan, Y., G. Miguez-Macho, C.-P. Weaver, R. Walko, and A. Robock, 2007: Incorporating water table dynamics in climate modeling: 1 . Water table observations and equilibrium water table simulations. J. Geophys. Res., 112, D10125, doi:10.1029/ 2006JD008111.

Gedney, N., and P. M. Cox, 2003: The sensitivity of global climate model simulations to the representation of soil moisture heterogeneity. J. Hydrometeor., 4, 1265-1275.

,,-- H. Douville, J. Polcher, and P. J. Valdes, 2000: Characterizing GCM land surface schemes to understand their responses to climate change. J. Climate, 13, 3066-3079.

Güntner, A., 2009: Improvement of Global Hydrological Models Using GRACE Data. Surv. Geophys., 29, 375-397.

Haines, B., and Coauthors, 2003: Instrument of GRACE: GPS augments gravity measurements. GPS World, 14, 16-28.

Hanasaki, N., S. Kanae, and T. Oki, 2006: A reservoir operation scheme for global river routing models. J. Hydrol., 327, 22-41.

Hansen, M. C., R. S. Defries, J. R. G. Townshend, and R. Sohlberg, 2000: Global land cover classification at $1 \mathrm{~km}$ spatial resolution using a classification tree approach. Int. J. Remote Sens., 21, 1331-1364.

Kilmjaninov, V., 2007: Hydrological conditions for actions on prevention of ice flooding on the Lena River. Extreme Hydrological Events: New Concepts for Security, O. F. Vasiliev et al., Eds., NATO Science Series, Vol. 78, 279-284.

Kim, H., P. J.-F. Yeh, T. Oki, and S. Kanae, 2009: Role of rivers in the seasonal variations of terrestrial water storage over global basins. Geophys. Res. Lett., 36, L17402, doi:10.1029/ 2009GL039006.

Klees, R., E. A. Zapreeva, H. C. Winsemius, and H. H. G. Savenije, 2007: The bias in GRACE estimates of continental water storage variations. Hydrol. Earth Syst. Sci., 11, 1227-1241.

Koster, R. D., M. Suarez, A. Ducharne, M. Stieglitz, and P. Kumar, 2000: A catchment-based approach to modeling land surface processes in a general circulation model. Part 1: Model structure. J. Geophys. Res., 105 (D20), 24 809-24 822.

—, P. A. Dirmeyer, A. N. Hahmann, R. Ijpelaar, L. Tyahla, P. Cox, and M. J. Suarez, 2002: Comparing the degree of landatmosphere interaction in four atmospheric general circulation models. J. Hydrometeor., 3, 363-375.

Lawrence, D. M., and A. G. Slater, 2007: Incorporating organic soil into a global climate model. Climate Dyn., 30, 145-160.

Lettenmaier, D. P., and J. S. Famiglietti, 2006: Water from on high. Nature, 444, 562-563.

Masson, V., J.-L. Champeaux, C. Chauvin, C. Meriguet, and R. Lacaze, 2003: A global database of land surface parameters at $1-\mathrm{km}$ resolution for use in meteorological and climate models. J. Climate, 16, 1261-1282.

Miguez-Macho, G., Y. Fan, C.-P. Weaver, R. Walko, and A. Robock, 2007: Incorporating water table dynamics in climate modeling: 2. Formulation, validation, and soil moisture simulation. J. Geophys. Res., 112, D13108, doi:10.1029/2006JD008112.

Molod, A., H. Salmun, and D. Waugh, 2004: The impact on a GCM climate of an extended mosaic technique for the landatmosphere coupling. J. Climate, 17, 3877-3891.

Nash, J. E., and V. Sutcliffe, 1970: River forecasting through conceptual models. J. Hydrol., 10, 282-290.
Ngo-Duc, T., J. Polcher, and K. Laval, 2005: A 53-year forcing data set for land surface models. J. Geophys. Res., 110, D06116, doi:10.1029/2004JD005434.

_ , K. Laval, G. Ramillien, J. Polcher, and A. Cazenave, 2007: Validation of the land water storage simulated by Organising Carbon and Hydrology in Dynamic Ecosystems (ORCHIDEE) with Gravity Recovery and Climate Experiment (GRACE) data. Water Resour. Res., 43, W04427, doi:10.1029/2006WR004941.

Niu, G.-Y., and Z.-L. Yang, 2006: Assessing a land surface model's improvements with GRACE estimates. Geophys. Res. Lett., 33, L07401, doi:10.1029/2005GL025555.

Noilhan, J., and S. Planton, 1989: A simple parameterization of land surface processes for meteorological models. Mon. Wea. Rev., 117, 536-549.

Oki, T., and Y. C. Sud, 1998: Design of Total Runoff Integrating Pathways (TRIP)—A global river channel network. Earth Interactions, 2. [Available online at http://EarthInteractions. org.]

Prigent, C., F. Papa, F. Aires, W. B. Rossow, and E. Matthews, 2007: Global inundation dynamics inferred from multiple satellite observations, 1993-2000. J. Geophys. Res., 112, D12107, doi:10.1029/2006JD007847.

Ramillien, G., F. Frappart, A. Güntner, T. Ngo-Duc, A. Cazenave, and K. Laval, 2006a: Time variations of the regional evapotranspiration rate from Gravity Recovery and Climate Experiment (GRACE) satellite gravimetry. Water Resour. Res., 42, W10403, doi:10.1029/2005WR004331.

— , A. Lombard, A. Cazenave, E. R. Ivins, M. Llubes, F. Remy, and R. Biancale, 2006b: Interannual variations of the mass balance of the Antarctica and Greenland ice sheets from GRACE. Global Planet. Change, 53, 198-208.

Rodell, M., J. S. Famiglietti, J. Chen, S. I. Seneviratne, P. Viterbo, S. Holl, and C. R. Wilson, 2004: Basin scale estimates of evapotranspiration using GRACE and other observations. Geophys. Res. Lett., 31, L20504, doi:10.1029/2004GL020873.

Sacks, J. W., B. I. Cook, N. Buenning, S. Levis, and J. H. Helkow, 2008: Effects of global irrigation on the near-surface climate. Climate Dyn., 327, 22-41.

Schmidt, R., and Coauthors, 2006: GRACE observations of changes in continental water storage. Global Planet. Change, 50,112-126.

Seo, K.-W., C. R. Wilson, J. S. Famiglietti, J. L. Chen, and M. Rodell, 2006: Terrestrial water mass load changes from Gravity Recovery and Climate Experiment (GRACE). Water Resour. Res., 42, W05417, doi:10.1029/2005WR004255.

Sheffield, J., G. Goteti, and E. F. Wood, 2006: Development of a 50-year high-resolution global dataset of meteorological forcings for land surface modeling. J. Climate, 19, 30883111.

Swenson, S., and P. Milly, 2006: Climate model biases in seasonality of continental water storage revealed by satellite gravimetry. Water Resour. Res., 42, W03201, doi:10.1029/2005WR004628. , and J. Wahr, 2006: Post-processing removal of correlated errors in GRACE data. Geophys. Res. Lett., 33, L08402, doi:10.1029/2005GL025285.

- _ _ , and P. Milly, 2003: Estimated accuracies of regional water storage variations inferred from the Gravity Recovery and Climate Experiment (GRACE). Water Resour. Res., 39, 1223, doi:10.1029/2002WR001808.

Syed, T. H., J. S. Famiglietti, J. Chen, M. Rodell, S. I. Seneviratne, P. Viterbo, and C. R. Wilson, 2005: Total basin discharge for the Amazon and Mississippi River basins from GRACE and a land-atmosphere water balance. Geophys. Res. Lett., 32, L24404, doi:10.1029/2005GL024851. 
, V. Zlotnicki, and M. Rodell, 2007: Contemporary estimates of Pan-Arctic freshwater discharge from GRACE and reanalysis. Geophys. Res. Lett., 34, L19404, doi:10.1029/2007GL031254.

Tapley, B. D., S. Bettadpur, J. C. Ries, P. F. Thompson, and M. M. Watkins, 2004: GRACE measurements of mass variability in the Earth system. Science, 305, 503-505.

Velicogna, I., and J. Wahr, 2006a: Acceleration of Greenland ice mass loss in spring 2004. Nature, 443, 329-331.

, and — 2006b: Measurements of time-variable gravity show mass loss in Antarctica. Science, 311, 1754-1756.
Wahr, J., S. Swenson, V. Zlotnicki, and I. Velicogna, 2004: Timevariable gravity from GRACE: First results. Geophys. Res. Lett., 31, L11501, doi:10.1029/2004GL019779.

— - — , and I. Velicogna, 2006: Accuracy of GRACE mass estimates. Geophys. Res. Lett., 33, L06401, doi:10.1029/ 2005GL025305.

Yeh, P. J.-F., S. C. Swenson, J. S. Famiglietti, and J. Wahr, 2006: Remote sensing of groundwater storage changes in Illinois using the Gravity Recovery and Climate Experiment (GRACE). Water Resour. Res., 42, W12203, doi:10.1029/2006WR005374. 